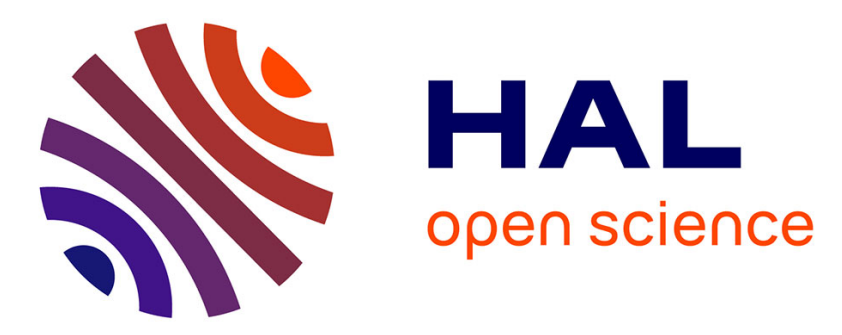

\title{
Linsey McGoey, 2015, No such thing as a free gift: The Gates foundation and the price of philanthropy, London, Verso, $304 \mathrm{p}$.
}

Edouard Morena

\section{- To cite this version:}

Edouard Morena. Linsey McGoey, 2015, No such thing as a free gift: The Gates foundation and the price of philanthropy, London, Verso, 304 p.. Review of Agricultural, Food and Environmental Studies, 2017, 98 (4), pp.323-326. 10.1007/s41130-018-0064-y . hal-03114846

\author{
HAL Id: hal-03114846 \\ https://hal.science/hal-03114846
}

Submitted on 19 Jan 2021

HAL is a multi-disciplinary open access archive for the deposit and dissemination of scientific research documents, whether they are published or not. The documents may come from teaching and research institutions in France or abroad, or from public or private research centers.
L'archive ouverte pluridisciplinaire HAL, est destinée au dépôt et à la diffusion de documents scientifiques de niveau recherche, publiés ou non, émanant des établissements d'enseignement et de recherche français ou étrangers, des laboratoires publics ou privés. 


\title{
Linsey McGoey, 2015, No such thing as a free gift: The Gates foundation and the price of philanthropy, London, Verso, 304 p.
}

\author{
Edouard Morena ${ }^{1}$
}

Published online: 6 March 2018

(C) INRA and Springer-Verlag France SAS, part of Springer Nature 2018

Over the past ten years in Europe, we have witnessed a steadily growing academic interest in philanthropic foundations and their role as agents of social change. Yet the overall level of public and scholarly interest in foundations remains limited. This is not surprising given the relatively small size of the foundation sector-in terms of number of foundations, endowments, and grantmaking levels (especially when compared to state funding).

In stark contrast, the USA concentrates the largest number of philanthropic foundations and the greatest levels of grantmaking. Countless non-academic and academic publications from this country have explored the functions, influence, and legitimacy of philanthropic foundations there and throughout the world. Far from playing a passive role, philanthropic foundations actually support much of this research. Foundations have helped turn "philanthropy studies" into a dynamic field of academic research and teaching. A number of universities offer degrees or topical courses in philanthropy. Some universities have their own research and teaching departments on philanthropy, funded in most cases by philanthropic foundations. For example, at Indiana State University, a school of philanthropy was set up with support from a private philanthropic foundation and with the mission of "increas[ing] the understanding of philanthropy and improv[ing] its practice worldwide through critical inquiry, interdisciplinary research, teaching, training, and civic engagement."1

What then, one might ask, does Linsey McGoey's book No Such Thing As A Free Gift bring to a field already replete with research centers and publications devoted to the study of philanthropic foundations? Additionally, why should non-specialists in philanthropy read her book rather than the countless other publications devoted to that topic?

${ }^{1}$ https://philanthropy.iupui.edu/about/index.html

Edouard Morena

Edouard.morena@ulip.lon.ac.uk

1 University of London Institute in Paris (ULIP), Paris, France 
Before exploring these questions, let's begin by briefly outlining the book's structure and main ideas. McGoey's book is broadly structured into two parts. In a first half, McGoey focuses on the history of philanthropy and investigates the rise of philanthrocapitalism. Throughout the various chapters, she draws on a series of richly documented case studies and offers a detailed analysis of some of the key texts that have inspired philanthropists and served to justify their actions over the past two centuries.

In the second half of the book, McGoey offers an in-depth analysis of the Bill and Melinda Gates foundation. She does so through a series of snapshots on the foundation's engagement in different areas and regions of the world. Drawing on on-sight observations and numerous interviews with foundation representatives, activists, charity volunteers, journalists, NGO staffers, and scholars, McGoey presents the Gates Foundation's actions in the fields of primary and secondary education, health, and agriculture. In Chapter 4, McGoey explores the ways through which the Gates Foundation, along with two other major philanthropic players in US education, the Walton Family Foundation and the Eli and Edythe Broad Foundation, have influenced political decision-making in the education sphere-particularly through their promotion of charter schools and their emphasis on standardized testing, despite questionable results in both cases.

In Chapter 5, she looks at the Gates Foundation's action in the area of health at the global level. She describes how the foundation, through its funding and public relations efforts, successfully contributed to orientate the global health research and policy agenda, despite contradictions between its avowed goals and investment decisions, prioritization of northern organizations and poor results. Chapter 6 looks at how Gates' personal views and business interests have influenced his foundation's strategy when it comes to eradicating some of the world's deadliest epidemics - in particular HIV/ AIDS, tuberculosis, and malaria. Rather than pushing for a fairer global patent regime, the Gates Foundation has favored a "charity handout" approach that is not conducive to a much-needed decline in the price of medicines.

In Chapter 7, McGoey presents the Gates Foundation's work in the field of agriculture. She shows how the foundation's investments in global agriculture and close connections with corporate entities like Goldman Sachs and Monsanto "may be compounding food insecurity rather than mitigating it." In particular, she offers a detailed and critical assessment of the Gates and Rockefeller Foundations' Alliance for a Green Revolution in Africa (AGRA) initiative, launched in 2006 and centered on the promotion of high-yield and genetically modified crop varieties.

Coming back to the merits of McGoey's research given the large amount of work already available, I feel that her book deserves our attention for three main reasons.

First, McGoey's book is essential reading for any scholar interested in contemporary development issues as it clearly shows how foundations exert a growing - and, at times, disproportionate - influence in the international development field. From largescale health epidemics to agricultural development, primary and secondary education, or microfinance, McGoey's detailed analysis demonstrates that, even though the amounts of money spent are only a fraction of government spending, philanthropic foundations are key players and orchestrators of contemporary development debates. Beyond their grantmaking activities, they orientate the international development agenda by imposing new themes and approaches in development thinking and practice. 
Second, McGoey breaks with the dominant mantra in much of the academic and non-academic literature devoted to philanthropy, which, broadly speaking, consists in commending philanthropists for their generosity and their work. In her book, McGoey runs counter to the dominant and widespread belief and discourse that consists in stating that philanthropy is necessarily a good thing. In this respect, her work fits into a small but growing field of critical studies that challenge the dominant assumptions about philanthropy and philanthropists (Jenkins 2011; Morena 2016; Parmar 2012).

Her analysis is all the more laudable that it centers on one of the world's largest, most active and most powerful private foundations - the Bill and Melinda Gates Foundation, whose founder and president is most often recognized, and even celebrated, for his philanthropic actions. Through her critical assessment of Gates' philanthropic activities, she invites us to scratch off the veneer of generosity and to explore the underlying motives that have led Gates to devote a significant portion of both his time and fortune to some of the most pressing challenges of our time. In addition to the motives, she also discusses the implications - both voluntary and involuntary - of giving for the target communities as well as its effectiveness.

Third, and while focusing on one foundation, McGoey's book offers a good overview of current trends in philanthropic giving. She offers a critical and welcome assessment of "philanthrocapitalism," which posits a methodological break with prior ways of doing philanthropy through more targeted, pro-active, and resultoriented commitments. By placing such trends in historical perspective, she questions their novelty and highlights their continuities with earlier approaches promoted by the "big three" founding fathers of modern philanthropy (Carnegie, Rockefeller, and Ford).

McGoey convincingly shows that contemporary philanthropic thinking abides by the same underlying ideology than that of the so-called robber barons. Drawing on the influential work of Bernard Mandeville - and in particular his Fable of the Bees (1705)-McGoey argues that philanthropists have always been driven by the belief that progress and the public good are fuelled by enlightened self-interest. In other words, private gain serves the public welfare. As she writes, "philanthrocapitalism is the proud embodiment of a once phantom theory [whose] proponents unabashedly claim that trickle-down policies are our best answer for combating growing economic and social inequalities."

What, according to McGoey, clearly sets contemporary philanthropists apart from their predecessors is that whereas before, philanthropists, given peoples' hostility towards them, did not explicitly voice these underlying motives, today, philanthropists such as Gates "are increasingly proud, triumphant even, about the private economic fortunes to be made through embracing philanthrocapitalism." As she goes on to write, "not only is it no longer necessary to 'disguise' or minimize self-interest, self-interest is championed as the best rationale for helping others."

This fundamental shift in philanthropic discourse is both the engine and symptom of a broader ideological shift in society as a whole. It has become widely accepted-and foundations have played no small part in making this happen-that self-interest is not only compatible with but more fundamentally a prerequisite for altruism. In this respect, popular perceptions of philanthropy and philanthropists' self-representation are particularly revealing of the current state of our societies and reining ideology. 


\section{References}

Jenkins, G. (2011). Who's afraid of philanthrocapitalism? Case Western Reserve Law Review, 61(3), 753. Morena, E. (2016). The price of climate action: philanthropic foundations and the international climate debate. Palgrave.

Parmar, I. (2012). Foundations of the American century: the Ford, Carnegie, and Rockefeller Foundations in the rise of American power. New York: Columbia University Press. 